\title{
THE UK's PRIVATISATION EXPERIMENT: THE PAssage of Time Permits a Sober Assessment
}

\author{
DAVID PARKER
}

CESIFo Working PAPER No. 1126

CATEGORY 9: INDUSTRIAL ORGANISATION

FEBRUARY 2004

Presented at CESifo CONFERENCE ON PRIVATISATION EXPERIENCES IN THE EU NOVEMBER 2003 


\title{
THE UK's PRIVATISATION EXPERIMENT: THE PASSAGE of Time Permits a SOBER ASSESSMENT
}

\begin{abstract}
This chapter looks at the UK's privatisation experiment, which began from the late 1970s. It considers the background to the UK's privatisations, which industries were privatised and how, and summarises the results of studies of performance changes in privatised companies in the UK. It looks at the relative roles of competition, regulation and ownership changes in determining performance improvement. It concludes by looking at the wider lessons that might be learned from the UK's privatisation experiment, including the importance of developing competitive markets and, in their absence, effective regulatory regimes.
\end{abstract}

Keywords: UK, privatisation, competition regulation, lessons.

JEL Classification: L33, H82, L51.

David Parker

Cranfield University School of Management

Cranfield

Bedfordshire MK43 OAL

United Kingdom

david.parker@cranfield.ac.uk 


\section{Introduction}

The Labour Government of 1974-79 arranged the sale of some of the state's shareholding in the petroleum company BP. However, this sale was dictated by budgetary pressures and did not reflect a belief within government that state industries should be privatised. Indeed, the same Labour Government took into state ownership two major industries, namely aerospace and shipbuilding. Only with the election of a Conservative Government in 1979, led by Margaret Thatcher, did a sea change in attitude occur within government towards the role of the state in the economy. Although it is often pointed out that the Conservative Party election manifesto in 1979 paid little attention to what became known as 'privatisation', referring in the main simply to restoring to the private sector the two industries recently nationalised by labour, there was no doubting in 1979 Mrs Thatcher's personal crusade against state ownership. As she writes in her memoirs:

'Privatization... was fundamental to improving Britain's economic performance. But for me it was also far more than that: it was one of the central means of reversing the corrosive and corrupting effects of socialism....... Just as nationalization was at the heart of the collectivist programme by which Labour Governments sought to remodel British society, so privatization is at the centre of any programme of reclaiming territory for freedom.' (Thatcher, 1993, p.676)

Table 1 provides a summary of the major privatisations during the 1980s and 1990s ${ }^{1}$ and Table 2 a summary of the amounts raised through state asset sales in the same period. Privatisation receipts peaked in the UK in the early 1990s. In 1997 a new Labour Government was elected, but despite promises when in opposition to reverse at least some of the privatisations, this government has continued its own, though much smaller-scale privatisations, especially in the form of 'public-private partnerships' (Parker and Hartley, 2003).

(Tables 1 and 2 here.) 
The passage of time since the commencement of the UK's privatisation programme in the early 1980s now permits a sober assessment of the results, looking at the longerterm evidence. We start the discussion of the UK's privatisation experiment by considering its main characteristics. We then turn to consider its results in terms of its affects on economic performance. A number of studies have been undertaken into the results of privatisations in the UK and we provide a summary of key studies, a number of which were undertaken by the author of this paper. As we shall see, the results confirm what we might expect from economic theory and that is that changes in ownership lead to performance improvements where there are appropriate changes in the competitive or regulatory environments. The chapter concludes by considering the wider lessons for economic policy of the privatisation experiment within the UK.

\section{Privatisation in the UK}

As the details in Tables 1 and 2 confirm, the UK's privatisation experiment began cautiously. Unlike in a number of other countries, no 'privatisation plan' was published by government setting out a timetable for future privatisations. Rather the policy evolved with each seemingly successful sale - defined in terms of the government's ability to sell the enterprise - triggering the planning of a further sale. Some privatisations were postponed for a number of years, for example British Airways from 1980 to 1987, in the face of difficult economic conditions for the airline, while others seem to have been sold quickly and opportunistically, such as Jaguar cars in 1984. Although government denied that the privatisations were determined by the need to raise annual revenues for government to support tax cuts and public expenditure plans, and in relation of tax and spending levels privatisation receipts were always small, it does not seem that generating government funds was an irrelevant consideration in the timing of privatisations throughout the 1980s. The Thatcher government set about introducing a lower tax regime in the UK from 1980 but lacked the ability or willpower to cut public expenditure dramatically (Burton and Parker, 1991). Annual privatisation revenues helped fund some of the gap. At the

\footnotetext{
${ }^{1}$ A fuller listing, including 119 organisations, can be found on the HM Treasury website: www.hm-
} 
same time, a fully articulated rationale for privatisation was never formally provided by government. With some justification Kay and Thompson titled their early study of the UK's experience in the Economic Journal in 1986, 'Privatisation: a Policy in Search of a Rationale'. More recently the various studies in Parker and Saal (2003) illustrate the great diversity in rationales for privatisation that still exist worldwide.

The first major privatisations in the UK occurred in the early 1980s and involved reversing the Labour Government's nationalisations of the 1970s. British Aerospace, formed under state ownership from three private sector aerospace companies in 1977, was privatised in 1981 through an initial public offering or IPO of 51.6 per cent of the shares. The state enterprise that controlled the shipbuilding industry, British Shipbuilders, by contrast, was split up and sold off piece meal. Another high focus sell-off involved the state's road-freight and storage business, the National Freight Corporation, which had almost gone bankrupt in the mid-1970s. This sale in 1982, unusually for a large privatisation, involved a management and worker buy-out. Other early privatisations involving IPOs included state enterprises that the public in general were almost certainly unaware of. Good examples were Amersham International and Enterprise Oil, which specialised in science-based products and North Sea oil production respectively. The Thatcher government also began an ambitious sale of the state's stock of housing ('council housing'), although other areas of the welfare state were little affected by privatisation. Privatisation of welfare services, especially health and education, were seen as a step too far politically. In the face of public concern that the Conservatives might dismantle the NHS, Mrs Thatcher repeatedly confirmed that 'the NHS is safe with us' - to the undoubted disappointment of some of her supporters (Berry, 2002, p.2).

Sell-offs took a number of forms including IPOs (mainly through offers for sale but some through sales by tender ${ }^{2}$ ), trade sales (e.g. the sale of Rover cars formerly British Leyland to British Aerospace in 1988), private placements in favour of institutional investors and, on occasions, management and worker buy-outs (e.g.

treasury.gov.uk/documents/enterprise and productivity/public_enterprise

${ }^{2}$ Under offers for sale the sale price is set and publicised in advance, whereas under sale by tender broadly the price is set by demand and supply during the sale. Offers for sale provide more certainty regarding the purchase price and therefore are more attractive to small investors. They also offer the best prospects for a quick capital gain on selling the shares shortly after privatisation. 
National Freight, some shipyards and a few coal mines). The early industry state selloffs involved businesses that were in competitive markets. Aerospace and shipbuilding, for example, faced intense international competition for orders; indeed, in the face of such competition the UK shipbuilding industry was in terminal decline, something privatisation failed to reverse. The National Freight Corporation faced competition from numerous smaller domestic private freight companies and while state owned never held more than 10 per cent of the UK market for freight and storage services. By contrast, a number of the major privatisations from the mid-1980s involved state enterprises that operated in monopoly markets, These firms are often referred to as 'public utilities' or 'network industries', reflecting their economies of scale and scope, and include telecommunications, gas, water and sewerage, electricity and rail transport. Previously they had been seen as 'natural monopolies' and therefore unsuitable for private ownership.

Official policy on the ownership of the public utilities began to change in 1982/83. Telecommunications experienced fast technological change that reduced its earlier natural monopoly characteristics, such as optical fibre cables, new switching gear and wireless-based technologies. At the same time, technological change necessitated large-scale investment to meet the expected demands for telecommunications services, especially data transmission and cellular phones, which the UK government with its budgetary problems felt unable to meet. In 1980 British Telecom (BT) had been separated from the Post Office into a new 'public corporation' owned by government. In 1983 the decision was taken to privatise BT. The 1984 Telecommunications Act led to the flotation of 50.2 per cent of BT's shares in the stock market in December of that year; ${ }^{3}$ the remainder of the shares were sold by government in two further tranches, in December and July 1993. In 1983 BT had an entire monopoly of telecommunications services and equipment supplies within the UK. The provision of equipment was first opened to competition, in spite of protests from BT on 'safety' grounds, and in 1984 a new fixed-line operator was licensed, Mercury Communications (later fully-owned by Cable and Wireless the UK-based international telecommunications company, itself privatised between 1981 and 1985). 
To protect the consumer from monopoly abuse until competition developed, a new telecommunications regulator, the Office of Telecommunications (OFTEL), was hastily created. Initially, during the planning of BT's privatisation, it seems that government intended to regulate BT using normal competition law. But in the face of concerns from the Office of Fair Trading (the government's competition department) about the expected workload and need to build up specialist telecommunications regulation expertise, the decision was taken to include in the Telecommunications Bill provision to establish OFTEL.

The BT privatisation was a success in the sense that the IPO was greatly oversubscribed. Concerned that the London stock market might not absorb what was then the largest single flotation in the market's history, the government had mounted a campaign, including TV and press advertising, to attract the small investor. The result was an outstanding success. Instead of the expected widespread public opposition to the privatisation of BT - in a sense the public already 'owned' BT as a state enterprise and therefore might have been expected to object to being asked to buy shares in the company - the public backed the sale through share buying. The outcome was a landmark in the UK's privatisation experiment, for a number of reasons.

Firstly, the sale of BT established the principle that the public utilities could be soldoff in spite of their size; secondly, Oftel became the regulatory model for later sector regulatory offices for gas (Ofgas), water and sewerage (Ofwat), electricity (Offer) and the railways $(\mathrm{ORR})^{4}$; and thirdly, the sale proved that small investors could be attracted if the shares were sold at a discount. ${ }^{5}$ This helped to meet the Conservative's objective of creating a share-owning democracy as a bulwark against socialism - a number of later privatisations included provisions that favoured small shareholders. In 1986 British Gas was privatised, followed in 1989 by the water industry and 1990/91 by the electricity power industry (excluding nuclear generation, which was partially

\footnotetext{
${ }^{3}$ A small percentage of shares were reserved for employees of BT. This was a model copied for a number of subsequent privatisations.

${ }^{4}$ Today Ofgas and Offer have merged to form Ofgem (the Office of Gas and Electricity Markets). The railways now have another regulator, alongside the ORR, in the form of the Strategic Rail Authority (SRA).

${ }^{5}$ Nigel Lawson, Chancellor of the Exchequer from 1983 to 1989, notes in his memoirs (Lawson, 1992, p.210) that the government stumbled by accident on the popularity of selling shares at a discount to the public when it accidentally under-priced the sale of Amersham International in 1982.
} 
privatised later, in 1996, as British Energy). ${ }^{6}$ In all cases incentives were created for small investors to buy shares including loyalty share bonuses and discounts on utility bills. The percentage of adults holding shares consequently rose during the 1980s, from around 7 per cent to 25 per cent. However, small investors held only very small percentages of the total stock of each enterprise and the long-run trend towards increased institutional share ownership in the UK continued (Buckland, 1987). The share of the stock market accounted for by private investors fell from 28 per cent in 1989 to under 17 per cent by 1997. Moreover, arguably, effective corporate governance is better achieved by creating blocks of large shareholdings - and therefore investors with a large individual stake in the future of the business - rather than small shareholdings (for a review of the relevant literature on share ownership and corporate governance, see Filatotchev, 2003). It was, therefore, by no means selfevident that promoting the small shareholder through privatisation was consistent with the objective of raising economic efficiency in the enterprises sold. As events unfolded, however, many small shareholders sold their holdings to make a quick, and effortless, capital gain. For example, of the $2.2 \mathrm{~m}$. initial shareholders in BT, some 500,000 left the share register within six months (Ernst and Young, 1994, p.21).

In 1980 inter-urban coach services were opened up to competition with some resulting success in terms of lower fares and improved services. However, National Express, originally state owned, maintained dominance in the sector assisted by its entrenched position operating out of Victoria coach station in London. In 1992 National Express was floated in the stock market. In 1985 local bus transport was also liberalised (except for services in London) and tenders for routes were organised. ${ }^{7}$ The overall results were less positive. A number of towns faced a concentration of services on the profitable routes, some saw unruly competitive practices such as cutting in front of competitor buses to reach passengers first, and experienced other practices aimed at driving out rival operators. During the late 1980s many local bus services were privatised and, while total costs per passenger journey fell, fares rose and the longterm trend of a decline in bus passengers continued outside of London (Fawkner,

\footnotetext{
${ }^{6}$ British Energy owns eight nuclear stations excluding the older Magnox stations, which remain stateowned.

${ }^{7}$ Bus services in London were put out to tender more gradually, between 1985 and 1994.
} 
2003). The industry quickly consolidated ${ }^{8}$ and the UK competition authorities on a number of occasions investigated anti-competitive practices in the industry, especially the suspected use of predatory pricing. In 1993 the decision was taken to extend privatisation to the railways. The privatisation of the railways occurred between 1995 and 1997 and has proven especially controversial. We return to rail privatisation later in the chapter.

Across the EU, European Commission Directives have played a part in stimulating privatisation. Directives have required, in particular, the opening up of telecommunications (European Commission 96/19) and electricity power (European Commission 96/92) to competition. There have also been measures liberalising the provision of services in posts, gas and rail transport. However, because the UK has been a leader in privatisation (except in postal services, see below), the EU directives have not been the same stimulus for privatisation in the UK as they have been in some other parts of Europe (ed. Parker, 1998; Clifton et al., 2003). The EU directives have impacted in the UK in terms of harmonisation of regulatory rules across Europe rather than in terms of triggering state asset disposals (Daßler and Parker, 2003).

\section{The Results for Economic Performance}

There have been a number of empirical studies of the impact of UK privatisations on economic performance, adopting a range of performance measures to assess changes in allocative and productive efficiency and distributional effects. But most commonly, studies have concentrated on productive efficiency measuring changes in profitability, productivity and costs of production. Whereas profit is a useful measure of productive efficiency in competitive markets, its use in imperfectly competitive conditions is problematic because profits may reflect higher prices rather than more efficient production practices. For this reason, productivity and cost calculations are usually preferred when assessing productive efficiency in the (monopoly) public utilities. However, productivity measures which involve all inputs - i.e. measuring total factor

\footnotetext{
${ }^{8}$ By 1999 five operators - FirstGroup PLC, Arriva PLC, Stagecoach Holdings PLC, The Go-Ahead Group PLC and the National Express Group PLC - accounted for an estimated 69 per cent share of the local bus service market; www.researchandmarkets.com
} 
productivity with productivity gains shown as a residual - face reliability problems. This is because the capital input is usually difficult to measure accurately. At the same time, the alternative of measuring labour productivity trends may produce biased results due to capital for labour substitution and, where output rather than value added is used as the numerator, contracting-out of labour intensive services. At the same time, calculating efficient costs of production involves specification of a cost function. To overcome problems in specifying the appropriate functional form, some studies adopt mathematical modelling techniques including non-parametric frontier estimation using data envelopment analysis (DEA), which capitalises on Farrell's (1957) earlier exposition of the 'efficiency frontier' ${ }^{9}$ But DEA as a technique is sensitive to outliers and it assumes that all of the unexplained data variance results from inefficiency. Recently, an alternative parametric approach involving stochastic cost frontiers (SCF) has attracted interest, but the properties of SCF are not well understood and so far the method has been little used to assess the performance of privatisations in the UK.

Table 3 provides a summary of key studies of the impact of privatisation on economic efficiency in the UK, detailing the author, the industry, the performance measures used and the main findings. Most of the studies in Table 3 have been concerned with productive efficiency, although some have attempted to assess wider social welfare impacts. Investigation of the price-cost wedge, required in allocative efficiency studies, is complex and requires information on a firm's efficient costs of production and price-cost margins elsewhere in the economy (to address the 'second best' problem; Lipsey and Lancaster, 1956). Where markets become more competitive after privatisation, it might be expected that prices would move closer to marginal costs, implying higher allocative efficiency. However, this depends upon the pricing strategy followed under state ownership. Under state ownership and constant cost production, a 'break-even' objective will lead to prices equalling marginal costs and a profit-maximising, unregulated, monopolist produces a lower output than a state enterprise with a break-even strategy. Also, in empirical studies it often proves difficult to separate out the effects of ownership, competition, regulation and

\footnotetext{
${ }^{9}$ An extension of DEA analysis leads to Malmquist indices to reflect productivity growth.
} 
technological change on efficiency. Therefore it is often unclear how far privatisation rather than other factors is responsible for any economic efficiency gains achieved.

(Table 3 here.)

Principal-agent theory and its implications for effective corporate governance suggest that in privately-owned enterprises management faces superior incentives to drive out waste and maximise productivity (De Alessi, 1980; Bös, 1991; Boycko et al., 1996). ${ }^{10}$ While public choice theory maintains that within government, as elsewhere in the economy, self-interest is the dominant motive, with the result that state ownership is associated with empire building, gold plating of public investments, over-manning and, in general, economic waste (Niskanen, 1971; Tullock, 1976; Mitchell, 1988). Together, principal-agent theory and public choice theory provide a powerful theoretical rationale for privatisation (Boycko, Shleifer and Vishny, 1996). However, it is far from clear that politicians are aware of the details of the two theories, although they may have reacted as if they did. Nor, indeed, is it obvious that economic theory played the dominant part in the form and timing of privatisations in Europe (ed. Parker, 1998). Also, a fuller economic appraisal of privatisation (e.g. Kay and Thompson, 1986; Vickers and Yarrow, 1988; Martin and Parker, 1997) demonstrates that if ownership change is to have reliable efficiency results then the roles of competition and regulation may be crucial.

Turning to the studies in Table 3, a number were unable to reject the null hypothesis that ownership change has had no effect on economic performance. Nor is there any evidence that later privatisations outperformed earlier privatisations in terms of raising performance, which would have been consistent with 'learning' effects within government. In a number of cases the improvements in productive efficiency recorded simply reflected long-run growth trends that pre-dated privatisation. In the most comprehensive study of UK privatisation, by Martin and Parker (1997), for example, no consistent relationship between ownership and performance was found. For example, labour productivity growth in BT and British Gas fell after privatisation, and recovered sharply only after both telecommunications and gas supplies were opened 
up to more competition; in telecommunications this occurred in the early 1990s and in gas during the 1990s. In both industries, at first the regulatory pressures (including the price caps imposed by the regulatory offices) seem to have provided generous scope to raise profits without major cost cutting. In the face of tightening regulation and more competition in the 1990s, productivity responded. The average annual rise in labour productivity was around 15 per cent in BT and 6 per cent in British Gas in the early to the mid-1990s (with lower growth in total factor productivity). Since then the continued growth of competition has spurred further productivity gains.

The findings in Martin and Parker on the importance of competition and regulation are mirrored in a number of the other studies in Table 3; for example those relating to the electricity industry. In electricity competition was introduced at privatisation in 1990/91 and extended to all consumers during the 1990s. ${ }^{11}$ Burns and Weyman-Jones (1994) in an early study concluded that the 12 regional electricity distribution companies had become more efficient after privatisation, although this was a continuation of a longer-term trend. While a recent review of electricity generation found that substantial cost reductions had occurred (Newbery and Pollitt, 1997) and another study (Domah and Pollitt, 2001) of the performance of regional electricity companies in England and Wales calculates a significant gain in social welfare, but in both cases with gains skewed to producers (in terms of higher profits) and possibly government (in terms of higher tax revenues). In electricity like the other utility industries these efficiency increases were a reflection of the sharp reductions in employment achieved. Employment in the industry fell from 127,300 at privatisation to around 66,000 by $1996 / 97$. Over the same period transmission operating costs fell by nearly 40 per cent (Financial Times, 1999). In BT employment declined from around 238,000 at privatisation to 124,700 by 1999 , and in British Gas from about 92,000 at privatisation to 70,000 by 1994 .

Turning to the water industry where there is still very little competition, Shaoul (1997) concluded that significant efficiency gains, defined as lower costs relative to output, occurred before privatisation. After privatisation, at first employment in the

\footnotetext{
${ }^{10}$ In the 1970 s the term property rights theory was used but today the term principal-agent theory is preferred in the literature.

${ }^{11}$ Except in Northern Ireland, which has its own electricity system.
} 
industry rose, in 1990/91 the average number employed in the water and sewerage companies was 45,863. By 1993/94 this had grown to 58,270. More recently numbers have fallen and the water regulator's price caps imposed in 2000 necessitated, for the first time, real price reductions for water and sewerage services. What appears to have happened in this industry is that lax regulation at the outset plus a lack of competition combined to keep efficiency incentives weak in the early years (Saal and Parker, 2000, 2001. ${ }^{12}$

In the case of all of the privatisations, results may well have been affected by technical change. This is particularly so in telecommunications and electricity generation where there have been some notable technological improvements. Changes in international prices, notably for fuel inputs such as oil and gas, have also been an important factor in the electricity sector. One way forward is to compare the performance of the UK utilities with those overseas and able to capitalise equally on the new technologies and affected by the same world price movements for key inputs. In this respect O'Mahony's (1998) work on comparative productivity levels in the electricity, gas and water sectors in the US, France, Germany and Japan compared with the UK is of interest. Table 4 reproduces some of her results. It is evident that her calculations suggest that the labour and total factor productivity gap between the UK and the other countries has narrowed, but that in most cases this narrowing dates back to the late 1970s or before. That is to say, the catching up in comparative productivity pre-dates privatisation, a result consistent with the findings of some of the studies in Table 3. For example, Parker and $\mathrm{Wu}$ (1998) found that comparing the British steel industry with a number of other steel industries around the world, the relative performance of British Steel declined after privatisation. British Steel improved its performance sharply in the last few years under state ownership, when the industry was rationalised, capacity and manning cut, and the industry became attractive to private investors. It remains a matter of speculation whether the rationalisation occurred because of the imminent threat of privatisation, for which privatisation can take credit, or whether it simply provided the opportunity for

\footnotetext{
${ }^{12}$ In the water and sewerage industry the need to raise capital investment also led to real price increases, see the discussion of funding needs below. Saal and Parker attempt to control for environmental and water quality improvements in their econometric studies of productivity and costs in the water sector.
} 
government to sell-off the industry. ${ }^{13}$ Florio (2002; also see Brau and Florio, 2001 and Florio and Grasseni, 2003), using social-cost benefit analysis, concludes that British privatisations had modest effects on the efficiency of production and consumption, but that they did have important and regressive effects on the distribution of income and wealth. Overall, he concludes that there was not an unambiguous Pareto welfare improvement.

(Table 4 here.)

In most of the UK public utilities prices have fallen since privatisation reflecting gains in productive efficiency. The following examples are selected to reflect the general nature of the price changes after privatisation (a more detailed account can be found in Parker, 1999a, p.127). Taking telecommunications first, from 1984 to 1999 average real charges fell by around 48 per cent on average; although this change certainly results from technology and competition in addition to ownership change and regulation. ${ }^{14}$ Turning to the gas sector, the next to be privatised after telecommunications, between 1986 and 1997 domestic gas bills fell by an average of 2.6 per cent a year, again in real terms. After 1997 the gradual introduction of competition in domestic gas supplies led to further cuts of up to 20 per cent. ${ }^{15}$ Real industrial and commercial gas prices fell over the same period by about 5 per cent a year.

In the electricity market the decline in charges for domestic consumers in England and Wales between 1990 and 1999 was around 26 per cent in real terms for domestic consumers; while the reduction for industrial and commercial consumers was even larger, totalling between 25 and 34 per cent - see Table 5 (Littlechild, 2000, pp.32-

\footnotetext{
${ }^{13}$ Nigel Lawson is in no doubt that privatisation deserves the credit: 'It was the process of preparing State enterprises for privatization, and the prospect of privatization, that initially enabled management to be strengthened and motivated, financial disciplines to be imposed and taken seriously, and costs to be cut as trade union attitudes changed' (Lawson, 1992, pp.239-40).

${ }^{14}$ Within this average, line rental charges rose in nominal terms and remained broadly constant in real terms over the period. There was a sharp fall in call charges, especially long-distance and international charges.

${ }^{15}$ After the domestic market was liberalised around one in four domestic consumers switched from the former monopoly supplier, British Gas, to a new supplier. Similarly, by June 2000 one in four customers had exercised their new right to change their electricity supplier (NAO, 2001, p.1).
} 
33). ${ }^{16}$ The main exception to this impressive track record on charging was registered in the water and sewerage industry. Here domestic charges rose sharply after privatisation, by over 40 per cent in real terms for average unmeasured water and sewerage bills (less for measured or metered services). The privatised water companies justified these increases in terms of the need to fund investments to modernise water and sewerage systems after years of under investment when in the state sector and to meet the requirements of EU water quality directives. But the scale of the increases may also reflect a lack of competition in water services since privatisation.

It is also important to recognise that the above figures are averages and conceal disparities in the distribution of the welfare gains between different consumer groups (Hancock and Waddams Price, 1995; Waddams Price and Hancock, 1998; Markou and Waddams Price, 1999; Florio, 2002; Waddams Price and Young, 2003). State ownership is associated with cross-subsidies and 'no undue discrimination' clauses that lead to uniform pricing. Privatisation, especially when coupled with competition, can be expected to lead to prices more closely related to the marginal costs of supplying different user groups, provided that the removal of cross-subsidies is acceptable to industry regulators. In practice, in the UK regulators have accepted the case for removing much of the cross-subsidy, on the grounds that it distorts price signals; although they have sometime acted to slow down their removal to avoid sudden large price adjustments. The result over the longer-term has been different price changes for different user groups. Users with lower marginal costs, usually large users or industry, have tended to receive bigger reductions in charges than smaller, often poorer consumers, which are individually more costly to serve (NAO, 2001). The result is that lower income groups have received smaller welfare gains from privatisation, and in some cases have lost out, especially from privatisation of energy supplies. In this sense it has not proved possible for regulators neatly to separate the pursuit of economic efficiency from the social consequences of their actions (Baldwin and Cave, 1999, pp.80-81). This is something formally recognised in the Utilities Act

\footnotetext{
${ }^{16}$ The electricity industries in Scotland and Northern Ireland are separately structured and competition has been less intense. In Scotland the reduction in domestic charges up to 1997 was about 7 per cent and in Northern Ireland a miserly 0.4 per cent.
} 
2000, which enables government to give guidance to the energy market regulator to take account of social and environmental as well as economic outcomes.

Service quality changes since privatisation are particularly difficult to summarise because service quality is multi-dimensional. Nevertheless, there is no substantial evidence that lower manning and price reductions in the public utilities have been at the expense of service quality; ${ }^{17}$ while for privatised companies operating in competitive environments, reducing service quality to the disadvantage of consumers leads to a loss of market share and therefore is not usually a commercially sensible option. In telecommunications, gas, water services and electricity performance targets for service quality have been introduced by the regulator, with penalties and compensation payments paid to consumers where service falls below target. Over the years the regulators have set more exacting service standards that have delivered service improvements. The result is evidence of improved service quality since privatisation across the privatised utilities, with the notable exception of the railways (for a review see Parker, 1999a), to which we now turn.

The privatisation of the railways in the mid-1990s involved an ambitious project to introduce competition by dividing the railways into an infrastructure operator, Railtrack (responsible for lines, signalling and major stations), 25 passenger train operating companies (most with monopolies of services on particular routes but with plans to introduce competition later - these plans were subsequently abandoned), 6 freight service companies (three were quickly merged into one to facilitate a successful sale), 3 companies leasing rolling-stock (known as Roscos) and numerous rail maintenance businesses and other specialised activities. The result was the disintegration of the monopoly British Rail and the replacement of management control of resource use across the industry by very large numbers of legal contracts (Tyrrall and Parker, 2003). Few now defend the form of this privatisation and its resulting transaction costs and pressures have developed to reintegrate parts of the industry (Pollitt, 1999). The train companies were successful in raising passenger numbers, by over 30 per cent in four years, but this led to train overcrowding.

\footnotetext{
${ }^{17}$ Perhaps the most publicised example of a decline in service quality outside of the railways occurred in telecommunications in 1987 when the number of functioning public telephone boxes fell sharply. The regulator quickly persuaded BT to increase maintenance spending.
} 
Although Pollitt and Smith (2002) - see Table 3 - paint a generally favourable picture of rail privatisation in Britain, their analysis ends in 2000 before a significant decrease in service reliability and the financial collapse of Railtrack. In October 2001 Railtrack was placed in administration. ${ }^{18}$ The government refused to increase its funding to the company while it remained under private ownership. In 2002 the government replaced Railtrack with Network Rail, a company limited by guarantee but effectively a new state enterprise - although government refuses to concede that this amounts to renationalisation of the rail infrastructure. What is certain is that the Ladbroke Grove, Hatfield and Potters Bar rail crashes between 1999 and 2002 and continuing (and in part consequential) delays and cancellations of train services have meant that rail privatisation has damaged the reputation of privatisation in general within the UK. It is interesting to note, however, that even in the $1980 \mathrm{~s}$, when the public was eagerly buying privatisation shares with the aim of making a quick capital gain, public opinion polls often recorded a majority against the policy of privatisation (Clifton et al., 2003, p.91).

Finally, a fuller analysis of the welfare gains from privatisation needs to address the distribution of the economic net benefits, which seems to have been regressive in terms of impact on income and wealth (Florio, 2002). Certainly the City has benefited from accountancy, legal, consultancy and flotation fees and as an investor (TUC, 1985a). At least $£ 780 \mathrm{~m}$. had been paid in fees and commissions by 1994 (Helm, 1995). Also, profitability was buoyant in the privatised utilities, especially in the early years after privatisation. For example, the rate of return on capital employed in the water industry rose from an average of 9.8 per cent at privatisation in 1989 to 11.1 per cent by 1996/97; in electricity the increase was larger, with average returns rising from around 4 per cent in generation and 6.5 per cent in distribution and supply to around 11 per cent and 8.8 per cent respectively, between 1990/91 and 1995/96. As a result, and because shares were sold at attractive prices, in part to encourage small investors, investors benefited from large and sometimes spectacular rises in share

\footnotetext{
${ }^{18}$ This High Court action meant that administrators appointed by government became responsible for running the company. The train operating companies have also turned to public subsidies, contrary to the plans for sharp year-on-year reductions in public financing at the time of privatisation. More than half have had to be rescued from increasing losses. The train operating companies are now benefiting
} 
values. While returns have varied, on average individual investors who bought shares in the privatised utilities at flotation obtained returns on their investment up to the end of April 1997 exceeding 10 per cent per annum in real terms. ${ }^{19}$ The average return in the water sector was 24 per cent and in the electricity distribution and supply sector 38 per cent a year. The latter figure was buoyed up by takeover bids in the mid-1990s for distribution and supply companies in England and Wales. ${ }^{20}$

Table 6 summarises the findings from a study of returns to investors in the privatised utilities, showing the returns obtained by investors if the shares were sold at the end of the first day of trading, after 1 year, 5 years and if the shares were still held on 30 April 1997. The gains on the first day of trading for initial share offers underline the attraction of the shares to small investors keen to make a quick profit and were generally significantly greater than usually occurs for IPOs in the UK stock market (Boyfield, 199\&0; Florio, 2002, p.21). Where privatisation shares were bought at flotation by foreign investors, there was a net welfare loss to the UK due to underpricing; when bought by domestic investors there was a redistribution of wealth from government or taxpayers to domestic shareholders.

(Table 5 here.)

Returns to investors in the UK following privatisation were high and it seems higher than government anticipated at the time of the sell-offs (otherwise presumably the government would have held out for a higher price for the shares at the time of their sale). The high profits and shareholder returns can be attributed either to the companies exploiting their market power in the face of lax regulation or to government under-estimating the scope for cost savings following privatisation. Opinion seems to be divided on which of these explanations is the more important, probably both apply (e.g. Boardman and Laurin, 1998; Dnes, et.al., 1998). What is clear is that the regulators have been able to respond fully only when the price caps

from fewer but larger franchises and longer franchise periods. The result is to replace competition for franchises ('competition for the market') with longer-term investment incentives.

${ }^{19}$ May 1997 saw the election of a Labour Government. This government imposed a $£ 5.2 \mathrm{bn}$. 'windfall profits' tax on the utilities, including the privatised airport operator BAA, in an attempt to recoup some of the large profits made.

${ }^{20}$ The figures quoted are internal rates of return based on capital gains, dividends and amounts invested; for the method of calculation see Parker, 1997. 
have come up for reconsideration, at so-called 'periodic reviews' (although some regulators, notably the water regulator, intervened earlier and in the other industries companies were successfully cajoled from time to time not to increase their prices by the maximum permitted under their price cap). Price cap reviews in the mid to late 1990s reduced revenues to the privatised utilities, leading to significantly lower profitability and returns to investors closer to the cost of raising capital (or a 'normal' return). It is in no small part for this reason, for example, that the privatised electricity companies, which proved such a tempting target for takeovers by foreign companies especially US-based utilities in the mid-1990s, have since been re-sold, often at a loss. $^{21}$

Another obvious gainer from privatisation has been the senior management, many of whom kept their jobs at privatisation (Cragg and Dyck, 1999; Martin and Parker, 1997, ch.9). The introduction of stock options and profit related bonuses has led to a large rise in the pay of senior management. This has led, in turn, to media and union criticism of privatisation's 'fat cats' (e.g. TUC, 1985b). At the same time, job losses, de-unionisation and changes to collective bargaining in a number of privatised enterprises (TUC, 1986; Ferner and Colling, 1991) have produced a widening of pay differentials between unskilled workers and skilled workers and, of course, top management. Study suggests that privatisation did not lead to an obvious fall in average wages in privatised companies (Martin and Parker, 1996) but differentials have widened. There has been much variation in employment trends across privatised businesses and changes in pay and employment to a degree reflect wider changes in the UK economy. It is worth noting that in some cases when large-scale redundancies occurred, e.g. BT in the early 1990s, many of those made redundant received generous redundancy packages. This means that in assessing the net benefits from privatisation, the effect on workers is particularly difficult to assess. ${ }^{22}$

A further possible gainer was government and therefore taxpayers, who substituted paying subsidies to and receiving future dividends from the nationalised industries,

\footnotetext{
${ }^{21}$ Another, more recent factor has been the introduction of the New Electricity Trading Arrangements for wholesale power that have reduced wholesale electricity prices and therefore profitability in generation. These new Arrangements were introduced in March 2001 and replaced the power pool introduced at privatisation and which had been subject to alleged gaming by the major generators. ${ }^{22}$ Also, many redundancies in privatised companies have been 'voluntary'.
} 
for the sale price plus future taxation on any higher profits earned after privatisation. There is evidence that the taxpayer has been a net gainer in a number of cases (e.g. Domah and Pollitt, 2001), but no means all and perhaps not overall. Shaoul (2003) provides a financial analysis of the privatisation of the National Air Traffic Services, through a PPP, which suggests the government faces higher financial costs to bail out the failing sale. Florio (2002) concludes that public sector net wealth declined sharply during the years of privatisation, reflecting in part the under-pricing of assets sold. He concludes (ibid., p.35), 'that underpricing was recovered through the fiscal dividend is unconvincing, 23

\section{Lessons from the UK's Experience}

By 2004 there is little left in the industrial sector in the UK to privatise, although the welfare state still remains largely untouched by privatisation. Apart from some competitive tendering for contracts, such as for cleaning hospitals and schools, and isolated examples of private companies being brought in to sort out under-performing educational and health services, the welfare state remains solidly state provided. ${ }^{24}$ Recently the Government recommended greater use of private companies and private capital in the provision of health care, but this has met with determined opposition from backbench Labour MPs and public sector trade unions.

The Conservative Government backed away from privatising the Post Office in 1994 because of the potential adverse impact on rural post offices and because of the possible loss of uniform postal charges across the UK. Many Conservative MPs are elected by rural constituencies and rural areas might expect to be losers from the introduction of private competition. The current Labour Government has tried to introduce further commercialisation of the Post Office, begun under the Conservatives, but similarly shows no desire (or the lack of political courage) to privatise the post. London Underground, by contrast, is currently subject to restructuring that will lead to private companies becoming responsible for the

\footnotetext{
${ }^{23}$ The windfall profits tax introduced by the Labour Government shortly after its election in 1997 was intended to recover some of the rents from asset under-pricing.
} 
infrastructure. This project is highly controversial but promoted by the Labour Government as an example of the benefits of public-private partnership (PPP). Indeed, most privatisations under Labour have taken the form of PPPs or PFIs (Private Finance Initiative, a close relation). The intention is to introduce the reputedly superior project management skills of the private sector into transport, defence, the NHS, education and other public services. By April 2003564 PFI deals had been agreed with a capital value of $£ 35$ bn. (Financial Times, 2003). However, the extent of the long-term cost savings to taxpayers from PPPs remains highly uncertain, especially since government may raise capital more cheaply than the private sector (Economist, 2003; Parker and Hartley, 2003). ${ }^{25}$ Meanwhile, one major privatisation under Labour using a PPP, the selling-off of the Civil Aviation Authority's National Air Traffic Services (NATS) mainly to a consortium of seven UK airlines, quickly ran into financial difficulty ${ }^{26}$, and like the railways and British Energy (nuclear power) ${ }^{27}$, has sought financial assistance from the government.

So what are the lessons from the UK's privatisation experiment for the UK and other countries? Firstly, the empirical evidence is consistent with economic theory and suggests that competition and in the absence of competition effective state regulation are important if privatisation is to lead to performance improvements, including lower prices and improved services. Ownership change on its own does not appear to have a significant effect in terms of improving economic performance where there is market dominance, especially in terms of welfare gains to consumers. Management in monopolies may seek an 'easy life' whether in the private or public sectors; while in private-sector monopolies management can meet investors' expectations of profits by simply raising prices. Although it is dangerous to try and generalise across very different industries with different competitive conditions at the outset, nonetheless, in

\footnotetext{
${ }^{24}$ The 1980s and 1990s saw an expansion in private sector provision of care homes for the elderly. However, more recently many have closed following a tightening of state financing.

${ }^{25}$ The extent to which the state really does have a lower cost of capital than the private sector remains controversial. Critics argue that the government raises capital more cheaply only by transferring default risk to tazpayers who are under-compensated for the risk.

${ }^{26}$ NATS was privatised in 2001 and the state retains a 49 per cent shareholding and a 'golden share'. Golden shares have been introduced in a number of privatisations and enable the government to protect the company from unwelcome takeover bids. However, in a number of cases the golden shares have been abandoned and recently the European Commission signalled its unhappiness at the use of golden shares and challenged their legality.

${ }^{27}$ British Energy's problems have been exacerbated by falling wholesale electricity prices under the New Electricity Trading Arrangements.
} 
general the UK evidence is consistent with economic theory in making competition first best in terms of reliably generating economic efficiency gains, followed, in the absence of competition by effective regulation, and lastly privatisation. At the same time, however, it would be wrong to dismiss the benefits of privatisation in the UK. Without privatisation it is probable that competition would not have been permitted or would have proved more difficult to produce, for example in electricity and gas supplies, and regulatory systems would have remained highly politicised. In other words, increased competition and improved state regulation of utilities may be a direct product of the privatisation process. It is educational that the UK had experimented with various reforms for its nationalised industries in the 1960s and 1970s in the face of poor performance, to little obvious advantage (NEDO, 1976) and governments had continued to protect state monopolies from the threat of competition. $^{28}$

Secondly, the UK's utility privatisations led to very high returns to some investors, at least until competition or regulatory pressures became effective. This meant that in the early days generally investors rather than consumers were the main gainers from privatisation of the public utilities. 'Stagging' gains in the first hours of trading in the shares of a newly floated company are commonplace in stock markets, but the gains from privatisation issues in the UK seem, on average, to have been exceedingly generous and beyond what was needed to ensure that the flotations were a success.

Thirdly, although space has precluded a full discussion of the development of economic regulation in the UK, and more specifically the evolution of the powers of the regulatory offices - Oftel, Ofgas, Ofwat, Offer and ORR - it is clear from the UK's experience that where firms are privatised with considerable market dominance developing effective regulation takes time, but is essential. One of the UK's main contributions to economic policy in recent years has involved improvements in our understanding of regulatory governance and the popularising of certain regulatory tools, most notably the price cap (Littlechild, 1983; Parker, 2002).

\footnotetext{
${ }^{28}$ In the early 1980 s the UK government attempted to encourage new entry into the electricity and gas markets without privatisation. The results were very disappointing in the face of the market dominance of the state-owned firms, who ultimately had recourse to tazpayer support.
} 
Fourthly, the enterprises that were privatised fell into no set pattern with some of the utilities remaining dominant in their sectors (for example, in spite of competition and regulation BT still accounts for around 70 per cent of domestic residential and 60 per cent of all business calls within the UK) ${ }^{29}$ and others (e.g. Amersham International) becoming indistinguishable from other private sector companies. The result is an industrial structure involving both monopolistic and competitive privatised companies. The supervision of privatised markets falls increasingly to the competition authorities, in the UK notably the Competition Commission, both to ensure alongside industry regulators that competition develops where it is absent, and to protect competition once it has been established. A further lesson from the UK's experience emphasises the importance of parallel developments in competition policy to police the privatised markets effectively to prevent monopoly abuse and to encourage new market entry. The UK strengthened its competition laws in 1998 with the Competition Act and in 2002 with the Enterprise Act. This legislation has increased the powers of the competition authorities to investigate and penalise collusive behaviour between companies and abuses of market power that lead to a substantial lessening of competition. Privatisation has not led to the withering away of the state, but rather to a reformulated role for government as a market regulator rather than a direct service provider (cf. Cook, 1998; Saal, 2003, p.578).

Finally, the UK's experiment with privatisation came after decades of relative economic decline. The election of Mrs Thatcher occurred because of growing public discontent with poor economic growth, rising inflation, growing unemployment and poor labour relations in the UK. Privatisation has not proved to be an economic miracle. But as part of the wider restructuring of the economy that occurred in the 1980s, involving tax cuts, public spending caps, trade union reform and the closure of declining industries, it has contributed to reversing the perception of the UK as 'the sick man of Europe' - albeit that the UK's GDP growth rate has not noticeably increased as a result. In particular, privatisation has played an important part in reducing the burden of the state in the UK economy. Whereas in 1979 nationalised industries accounted for 10.5 per cent of GDP, by 1993 the figure had fallen to 3 per cent and public sector employment fell by 1.5 million as a result of the sale of the

\footnotetext{
${ }^{29}$ The figures are lower for international calls (residential 58.6 per cent and business 40 per cent). For a
} 
industries (Talbot, 2001, p.288). Whereas the precise economic effects of UK privatisation remain uncertain and will continue to debated, as part of the wider restructuring of the economy undertaken in the 1980s the outcome appears less controversial.

detailed breakdown, see Oftel (2002, p.10). 


\section{References}

Baldwin, R. and Cave, M. (1999) Understanding Regulation: Theory, Strategy and Practice, Oxford: Oxford UP.

Berry, S. (2002) 'Thatcherism is Dead. Long Live Thatcherism!', www.libertarianalliance.org.uk

Bishop, M. and Green, M. (1995) Privatisation and Recession - the Miracle Tested, Centre for the study of Regulated Industries, London.

Bishop, M. and Thompson, D. (1992) 'Regulatory Reform and Productivity Growth in the UK's Public Utilities', Applied Economics, vol.24, pp.1181-90.

Boardman, A.E. and Laurin, C. (1998) ' The Performance of Privatized British Public Utilities and the Windfall Profits Tax', mimeo, Faculty of Commerce, University of British Columbia.

Bös, D. (1991) Privatization: A Theoretical Treatment, Oxford: Clarendon Press.

Boycko, M., Shleifer, A. and Vishny, R.W. (1996) 'A Theory of Privatisation', Economic Journal, vol.106, March, pp.309-19.

Boyfield, K. (1997) Privatization: a Prize Worth Pursuing, London: European Policy Forum.

Brau, R. and Florio, M. (2001) 'Privatisations as price reforms: an analysis of consumers' welfare change in the UK', Working Paper No. 19.2001, Milan: Dipartimento di Economia Politica e Aziendale, Universita degli Studi di Milano,

Buckland, R. (1987) 'The costs and returns of privatisation of nationalised industries', Public Administration, vol.65, no.3, pp.241-57.

Burns, P. and Weyman-Jones, T. (1994) 'Regulatory Incentives, Privatisation and Productivity Growth in UK Electricity Distribution', CRI Technical Paper 1, London: Centre for the study of Regulated Industries.

Burton, J. and Parker, D. (1991) 'Rolling Back the State? UK Tax and Government Spending Changes in the 1980s', British Review of Economic Issues, vol.13, no.31, pp31-66.

Clifton, J., Comín, F. and Fuentes, D.D. (2003) Privatisation in the European Union: Public Enterprises and Integration, Kluwer: Dordrecht.

Cook, P. (1998) 'Privatization in the UK', in D.Parker (ed.) Privatisation in the European Union: Theory and Policy Perspectives, London: Routledge. 
Cox, A., Harris, L. and Parker, D. (1999) Privatisation and Supply Chain

Management: On the effective alignment of purchasing and supply after privatisation, London: Routledge.

Cragg, M. and Dyck, I.J.A. (1999) 'Management control and privatization in the UK', RAND Journal of Economics, vol.30, no.3, pp.475-97.

Daßler, T. and Parker, D. (2003) 'Harmony or Disharmony in the Regulation and the Promotion of Competition in EU Telecommunications? A Survey of the Regulatory Offices', Utilities Policy (forthcoming).

De Alessi, L. (1980) 'The Economics of Property Rights: A Review of the Evidence', Research in Law and Economics, vol.2, pp.1-47.

Dnes, A.W., Kodwani, D.G., Seaton, J.S. and Wood, D. (1998) 'The Regulation of the United Kingdom Electricity Industry: an Event Study of Price-Capping Measures' Journal of Regulatory Economics, vol.13, pp.207-25.

Domah, P. and Pollitt, M.G. (2001) 'The restructuring and privatisation of electricity distribution and supply businesses in England and Wales: a social cost-benefit analysis', Fiscal Studies, vo.22, no.1, pp.107-46.

Economist (2003) 'Low marks for PFI', 18 January, p.31.

Ernst \& Young (1994) Privatization in the UK: The facts and figures: London: Ernst $\&$ Young.

European Commission, Electricity Directive 96/92/EC, Brussels: European Commission.

European Commission, Amending Directive 90/38/EEC with Regard to the Implementation of Full Competition in Telecommunications Markets, 96/19/EC: Brussels: European Commission.

Farrell, M.J. (1957) 'The Measurement of Productive Efficiency', Journal of the Royal Statistical Society A120, part 3, pp.253-81.

Fawkner, J. (2003) 'Lessons from UK Experience in the Privatisation of Public Transport', www.leipzig-conferences.de/april/pdf/speeches

Ferner, A. and Colling, T. (1991) 'Privatisation, Regulation and Industrial Relations', British Journal of Industrial Relations, vol.29, no.3, pp.391-409.

Filatotchev., I. (2003) 'Privatization and corporate governance in transition economies: theory and concepts', in Parker and Saal (eds.).

Financial Times (1999)‘Competition remains the top priority’, 18 October, p.23.

Financial Times (2002) 'Watchdog fines bus companies over cartel', 31 January, p.6. 
Financial Times (2003) 'Big exapansion planned in PFI projects', 11 June, p.6..

Florio, M. (2001) 'The welfare impact of a privatisation: the British Telecom casehistory, , Working Paper No. 08.2001, Milan: Dipartimento di Economia Politica e Aziendale, Universita degli Studi di Milano.

Florio, M. (2002) 'A state without ownership: the welfare impact of British privatisations 1979-1997', , Working Paper No. 24.2002, Milan: Dipartimento di Economia Politica e Aziendale, Universita degli Studi di Milano,

Florio, M. (2003) 'Does Privatisation Matter? The Long-Term Performance of British Telecom over 40 Years', Fiscal Studies, vol.24, no.2, pp.197-234.

Florio, M. and Grasseni, M. (2003) 'The Missing Shock: The Macroeconomic Impact of British Privatisation', , Working Paper No. 21.2003, Milan: Dipartimento di Economia Politica e Aziendale, Universita degli Studi di Milano,

Hancock, C. and Waddams Price, C. (1995) 'Competition in the British Domestic Gas Market: Efficiency and Equity’, Fiscal Studies, vol.16, no.3, pp.81-105.

Harris, L., Parker, D and Cox, C. (1998) 'UK Privatisation : its impact on procurement', British Journal of Management, vol.9, special issue, pp.S13-S26.

Haskel, J. and Szymanski, S. (1993) 'The Effects of Privatisation, Restructuring and Competition on Productivity Growth in UK Public Corporations', Department of Economics Working Paper no.286, London: Queen Mary and Westfield College.

Helm, D. (1995) British Utility Regulation: Principles, Experience and Reform, Oxford: Oxford University Press.

Hutchinson, G. (1991) 'Efficiency Gains through Privatization of UK Industries', in (eds.) K. Hartley and A.F. Ott, Privatization and Economic Efficiency: a Comparative Analysis of Developed and Developing Countries, Aldershot: Edward Elgar.

Kay, J. and Thompson, D.J. (1986) 'Privatisation: a Policy in Search of a Rationale', Economic Journal, vol.96, pp.18-32.

Lawson, N. (1992) The View from No.11: Memoirs of a Tory Radical, London: Bantam.

Lipsey, R. and Lancaster, K. (1956) 'The General Theory of Second Best' Review of Economic Studies, vol.24, no.1, pp.11-32.

Littlechild, S.C. (1983) Regulation of British Telecommunications' Profitability, London: HMSO.

Littlechild, S.C.(2000) Privatisation, Competition and Regulation, Occasional Paper 110, London: Institute of Economic Affairs. 
Markou, E. and Waddams Price, C. (1999) 'UK Utilities: Past Reform and Current Proposals', Annals of Public and Cooperative Economics, vol.70, no.3, pp.371-416.

Martin, S. and Parker, D. (1996) 'The Impact of UK Privatisation on Employment Profits and the Distribution of Business Income, Public Money and Management, vol.16, no.1, pp.31-38.

Martin, S. and Parker, D. (1997) The Impact of Privatisation: ownership and corporate performance in the UK, London: Routledge.

Mitchell, W.C. (1988) Government As It Is, Hobart Paper 109, London: Institute of Economic Affairs.

NAO (2001) Giving Domestic Customers a Choice of Electricity Supplier, Report by the Comptroller and Auditor General, HC 85 Session 2000-2001, London: Stationery Office.

NEDO (1976) A Study of UK Nationalised Industries: their Role in the Economy and Control in the Future, London: National Economic Development Office/HMSO.

Newbery, D. and Pollitt, M.G. (1997) 'The restructuring and privatisation of the CEGB - was it worth it?', Journal of Industrial Economics, vol.XLV, no.3, pp.269304.

Niskanen, W.A. Jr. (1973) Bureaucracy, Servant or Master?, London: Institute of Economic Affairs.

OFTEL (2002) Protecting Consumers - Oftel's New Price Control Proposals, ref. 08/02, London: Office of Telecommunications.

O’Mahony, M. (1998) 'Britain's competitive performance: an analysis of productivity by sector, 1950-1995', London: National Institute of Economic and Social Research.

Parker, D. (1994) 'A Decade of Privatisation: the Effect of Ownership Change and Competition on British Telecom', British Review of Economic Issues, vol.16, no.40, pp.87-113.

Parker, D. (1997) "Price cap regulation, profitability and returns to investors in the UK regulated industries", Utilities Policy, vol.6, no.4, pp.303-15.

Parker, D. (1998) 'Privatisation in the European Union: an overview', in D. Parker (ed.) Privatisation in the European Union: Theory and Policy Perspectives, London: Routledge.

Parker, D. (1999a) 'Regulating Public Utilities: Lessons from the UK', International Review of Administrative Sciences, vol.65, pp.117-31.

Parker, D. (1999b) 'The Performance of BAA Before and After Privatisation', Journal of Transport Economics and Policy, vol.33, part 2, pp.133-46. 
Parker, D. (2002) 'Economic Regulation: A Review of Issues', Annals of Public \& Cooperative Economics, vol.73, no.4, pp.493-519.

Parker, D. and Hartley, K. (2003) "Transaction costs, relational contracting and public-private partnerships: a Case Study of UK defence", Journal of Purchasing and Supply Management, vol.9, no.3, pp.97-108.

Parker, D. and Saal, D. (eds.) (2003) International Handbook on Privatization, Edward Elgar: Cheltenham.

Parker, D. and Wu, H.S. (1998) 'Privatization and Performance: A Study of the British Steel Industry under Public and Private Ownership', Economic Issues, vol.3, part 2, pp.31-50.

Pollitt, M.G. (1999) 'A survey of the liberalisation of public enterprises in the UK since 1979', in M. Kamagami and M.Tsuji (eds.) Deregulation and Institutional Framework, Institute of Developing Economies, External Trade Organisation: Tokyo.

Pollitt, M.G. and Smith, A.S.J. (2002) 'The restructuring and privatisation of British Rail: was it really that bad?', Fiscal Studies, vol.23, no.4, pp.463-502.

Saal, D. (2003) 'Restructuring, regulation and the liberalization of privatised utilities in the UK', in D. Parker and D.Saal (eds.).

Saal, D. and Parker, D. (2000) "The Impact of Privatisation and Regulation on the Water and Sewerage Industry in England and Wales: a translog cost function model", Managerial and Decision Economics, vol.21, pp.253-68.

Saal, D. and Parker, D. (2001 "Productivity and Price Performance in the Privatised Water and Sewerage Companies of England and Wales", Journal of Regulatory Economics, vol.20, no.1, pp.61-90.

Saundry, R. and Turnbull, P. (1997) 'Private profit, public loss: The financial and economic performance of U.K. ports', Maritime Policy Management, vol.24, no.4, pp.319-34.

Shaoul, J. (1997) 'A critical financial analysis of the performance of privatised utilities: the case of the water industry in England and Wales', Critical Perspectives on Accounting, vol.8, pp.479-505.

Shaoul, J. (2003) 'A Financial Analysis of the National Air Traffic Services PPP', Public Money \& Management, vol.23, no.3, pp.185-94.

Talbot, C. (2001) 'UK public services and management (1979-2000)', International Journal of Public Sector Management, vol.14, no.4, pp.281-303.

Thatcher, M. (1993) Margaret Thatcher: The Downing Street Years, Harper Collins: New York. 
TUC (1985a) Stripping Our Assets: The City's Privatisation Killing, London: Trades Union Congress.

TUC (1985b) Privatisation and Top Pay, London: Trades Union Congress.

TUC (1986) Bargaining in Privatised Companies, London: Trades Union Congress.

Tullock, G. (1976) The Vote Motive, London: Institute of Economic Affairs.

Tyrrall, D. and Parker, D. (2003) 'The Fragmentation of a Railway: A Study of

Organisational Change', mimeo, Cranfield University School of Management.

Vickers, J. and Yarrow, G. (1988) Privatization: an Economic Analysis, Cambridge MA: MIT Press.

Waddams Price, C.and Hancock, R. (1998) 'Distributional Effects of Liberalising UK Residential Utility Markets', Fiscal Studies, vol.19, no.3, pp.295-319.

Waddams Price, C. and Weyman-Jones, T. (1996) 'Malmquist indices of productivity change in the UK gas industry before and after privatisation', Applied Economics, vol.28, no.1, pp.29-39.

Waddams Price, C. and Young, A. (2003) 'UK utility reform: distributional implications and government response', in Ugaz, C. and Waddams Price, C. (eds.). Utility Privatization and Regulation: A Fair Deal for Consumers?, Cheltenham: Edward Elgar. 
Table 1: The UK's Major Privatisations

\begin{tabular}{|c|c|}
\hline & $\begin{array}{l}\text { Date of sale } \\
\text { (where more than one date is } \\
\text { given the shares were sold in } \\
\text { tranches) }\end{array}$ \\
\hline British Petroleum & $\begin{array}{l}\text { October } 1979 \\
\text { September } 1983 \\
\text { November } 1987 \\
\end{array}$ \\
\hline British Aerospace & $\begin{array}{l}\text { February } 1981 \\
\text { May } 1985\end{array}$ \\
\hline Cable \& Wireless & $\begin{array}{l}\text { October } 1981 \\
\text { December } 1983 \\
\text { December } 1985\end{array}$ \\
\hline Amersham International & February 1982 \\
\hline $\begin{array}{l}\text { National Freight Corporation } \\
\text { Britoil }\end{array}$ & $\begin{array}{l}\text { February } 1982 \\
\text { November } 1982 \\
\text { August } 1985\end{array}$ \\
\hline Associated British Port Holdings & $\begin{array}{l}\text { February } 1983 \\
\text { April } 1984\end{array}$ \\
\hline Enterprise Oil & July 1984 \\
\hline Jaguar & August 1984 \\
\hline British Telecommunications & $\begin{array}{l}\text { December } 1984 \\
\text { December } 1991 \\
\text { July } 1993\end{array}$ \\
\hline $\begin{array}{l}\text { British Shipbuilders and Naval } \\
\text { Dockyards }\end{array}$ & 1985 onwards \\
\hline British Gas & December 1986 \\
\hline British Airways & February 1987 \\
\hline Rolls-Royce & May 1987 \\
\hline BAA (British Airports Authority) & July 1987 \\
\hline British Steel & December 1988 \\
\hline Anglian Water & December 1989 \\
\hline Northumbrian Water & December 1989 \\
\hline North West Water & December 1989 \\
\hline Severn Trent & December 1989 \\
\hline Southern Water & December 1989 \\
\hline South West Water & December 1989 \\
\hline Thames Water & December 1989 \\
\hline Welsh Water & December 1989 \\
\hline Wessex Water & December 1989 \\
\hline Yorkshire Water & December 1989 \\
\hline Eastern Electricity & December 1990 \\
\hline East Midlands Electricity & December 1990 \\
\hline London Electricity & December 1990 \\
\hline Manweb & December 1990 \\
\hline Midlands Electricity & December 1990 \\
\hline
\end{tabular}




\begin{tabular}{|l|l|}
\hline Northern Electric & December 1990 \\
\hline NORWEB & December 1990 \\
\hline SEEBOARD & December 1990 \\
\hline Southern Electric & December 1990 \\
\hline South Wales Electricity & December 1990 \\
\hline South Western Electricity & December 1990 \\
\hline Yorkshire Electricity & December 1990 \\
\hline National Power & March 1991 \\
\hline PowerGen & March 1995 \\
\hline Scottish Hydro-Electric & June 1991 \\
\hline Scottish Power & June 1991 \\
\hline Trust Ports & $1992-97$ (various dates) \\
\hline Northern Ireland Electricity & June 1993 \\
\hline British Coal & December 1994 \\
\hline Railtrack & May 1996 \\
\hline British Energy & July 1996 \\
\hline AEA Technology & September 1996 \\
\hline Train Operating Companies & Various dates in 1996/7 \\
\hline National Air Traffic Services & July 2001 \\
\hline & \\
\hline & \\
\hline
\end{tabular}


Table 2: UK Privatisation Receipts: 1979-2000 (£bn.)

\begin{tabular}{|c|c|}
\hline $1977 / 78$ & 0.5 \\
\hline $1978 / 79$ & 0.0 \\
\hline $1979 / 80$ & 0.4 \\
\hline 1980/91 & 0.2 \\
\hline $1981 / 82$ & 0.5 \\
\hline $1982 / 83$ & 0.5 \\
\hline $1983 / 84$ & 1.1 \\
\hline $1984 / 85$ & 2.1 \\
\hline $1985 / 86$ & 2.7 \\
\hline $1986 / 87$ & 4.5 \\
\hline $1987 / 88$ & 5.1 \\
\hline $1988 / 89$ & 7.1 \\
\hline $1989 / 90$ & 4.2 \\
\hline 1990/91 & 5.3 \\
\hline $1991 / 92$ & 7.9 \\
\hline $1992 / 93$ & 8.2 \\
\hline $1993 / 94$ & 5.4 \\
\hline $1994 / 95$ & 6.4 \\
\hline $1995 / 96$ & 3.0 \\
\hline 1996.97 & 4.4 \\
\hline $1997 / 98$ & 1.8 \\
\hline $1998 / 99$ & 0.1 \\
\hline
\end{tabular}

Note: figures exclude council housing receipts and receipts of subsidiaries retained by the parent. The figures after 1998/99 are negligible.

Sources: HM Treasury, The Financial Statement and Budget Report (various). 
Table 3: UK Privatisation: Performance Studies

\begin{tabular}{|c|c|c|c|}
\hline Author(s) & Industry(s) & $\begin{array}{c}\text { Main Performance Measures } \\
\text { Used }\end{array}$ & Findings \\
\hline Hutchinson (1991) & $\begin{array}{l}17 \text { UK firms in several } \\
\text { industrial groupings }\end{array}$ & $\begin{array}{l}\text { Labour productivity, } \\
\text { profitability and technology } \\
\text { mix }\end{array}$ & $\begin{array}{l}\text { Privately-owned firms } \\
\text { outperformed comparable state- } \\
\text { owned firms in the 1970s and } \\
1980 \text { s in terms of profitability } \\
\text { only. Less certain whether } \\
\text { privatisation had improved } \\
\text { performance. }\end{array}$ \\
\hline Bishop and Thompson (1992) & $\begin{array}{l}9 \text { privatised enterprises across a } \\
\text { range of UK industries; } \\
\text { including BT, British Gas and } \\
\text { electricity supply }\end{array}$ & $\begin{array}{l}\text { Labour productivity and TFP, } \\
\text { 1970-80 compared with 1980- } \\
90\end{array}$ & $\begin{array}{l}\text { There was higher growth in } \\
\text { labour productivity in BT but } \\
\text { the growth in TFP fell in the } \\
1980 \text { s. In British Gas labour } \\
\text { productivity grew at the same } \\
\text { rate in the 1970s as the 1980s, } \\
\text { while the growth of TFP } \\
\text { declined. Electricity supply } \\
\text { saw a fall in both labour } \\
\text { productivity and TFP growth. }\end{array}$ \\
\hline Haskel and Szymanski (1993) & $\begin{array}{l}12 \text { privatised firms between } \\
1972 \text { and } 1988 \text {, including BT, } \\
\text { British gas, electricity supply } \\
\text { and water }\end{array}$ & $\begin{array}{l}\text { Estimates of productivity } \\
\text { growth (output per employee) }\end{array}$ & $\begin{array}{l}\text { In the main productivity has } \\
\text { grown faster in the } 1980 \mathrm{~s} \text {. } \\
\text { Competition is the significant } \\
\text { causal factor. }\end{array}$ \\
\hline
\end{tabular}




\begin{tabular}{|c|c|c|c|}
\hline $\begin{array}{l}\text { Burns and Weyman-Jones } \\
\text { (1994) }\end{array}$ & Electricity distribution & $\begin{array}{l}\text { Multiple input, multiple output } \\
\text { model of before and after } \\
\text { privatisation using } \\
\text { mathematical programming } \\
\text { techniques }\end{array}$ & $\begin{array}{l}\text { The } 12 \text { electricity distribution } \\
\text { companies have been more } \\
\text { efficient since privatisation, but } \\
\text { this continues a long-term } \\
\text { historical trend. There is also a } \\
\text { greater diversity of } \\
\text { performance amongst the } 12 \\
\text { since privatisation. }\end{array}$ \\
\hline Parker (1994) & $\begin{array}{l}\text { British Telecom (BT) 1979/80 } \\
\text { to } 1993 / 94\end{array}$ & $\begin{array}{l}\text { Productivity and employment } \\
\text { costs in total costs. R\&D } \\
\text { expenditures }\end{array}$ & $\begin{array}{l}\text { Labour productivity grown } \\
\text { faster since privatisation, but } \\
\text { the record for TFP is much less } \\
\text { impressive. Employment costs } \\
\text { have declined as a percentage } \\
\text { of all costs, continuing a trend } \\
\text { that dates back to before } \\
\text { privatisation. R\&D } \\
\text { expenditures as a percentage of } \\
\text { turnover have fallen, but this } \\
\text { result is difficult to interpret } \\
\text { because it may reflect a more } \\
\text { efficient use of resources. }\end{array}$ \\
\hline Bishop and Green (1995) & $\begin{array}{l}6 \text { privatised enterprises } \\
\text { including British Gas and BT }\end{array}$ & TFP and financial data 1989-94 & $\begin{array}{l}\text { Competition rather than } \\
\text { ownership is important. } \\
\text { Growth in TFP in BT was in } \\
\text { part due to technical change. }\end{array}$ \\
\hline $\begin{array}{l}\text { Waddams Price and Weyman- } \\
\text { Jones (1996) }\end{array}$ & Gas industry, $1977 / 78$ to 1991 & $\begin{array}{l}\text { Malmquist indices of } \\
\text { productivity growth }\end{array}$ & $\begin{array}{l}\text { Post-privatisation productivity } \\
\text { growth was around 5-6per cent } \\
\text { per annum compared with } 3 \text { per } \\
\text { cent a year before privatisation }\end{array}$ \\
\hline
\end{tabular}




\begin{tabular}{|c|c|c|c|}
\hline & & & $\begin{array}{l}\text { in } 1986 . \text { However, differences } \\
\text { remain in technical efficiency } \\
\text { amongst British Gas's regions. }\end{array}$ \\
\hline Newbery and Pollitt (1997) & Electricity generation & Various & $\begin{array}{l}\text { Labour productivity has more } \\
\text { than doubled since } 1990 \text {, } \\
\text { mainly due to shedding labour. } \\
\text { Real unit costs have declined. }\end{array}$ \\
\hline Shaoul (1997) & Water industry & Cost and output data & $\begin{array}{l}\text { Greater efficiency gains, } \\
\text { meaning lower costs relative to } \\
\text { output, occurred prior to } \\
\text { privatisation. }\end{array}$ \\
\hline Saundry and Turnbull (1997) & Ports & $\begin{array}{l}\text { Traffic and financial data } \\
\text { including capital expenditure, } \\
\text { mainly for the } 1980 \mathrm{~s} \text {. }\end{array}$ & $\begin{array}{l}\text { The UK's privatised ports did } \\
\text { not perform better than trust } \\
\text { ports and municipally-owned } \\
\text { docks. Service improvements } \\
\text { have came mainly from } \\
\text { employment de-regulation (the } \\
\text { abolition of the so-called Dock } \\
\text { Labour Scheme). }\end{array}$ \\
\hline Martin and Parker (1997) & $\begin{array}{l}11 \text { privatised organisations } \\
\text { studied including British Gas } \\
\text { and BT. Years before and after } \\
\text { privatisation included. }\end{array}$ & $\begin{array}{l}\text { Labour productivity, TFP, } \\
\text { various financial ratios and data } \\
\text { envelopment analysis (DEA) }\end{array}$ & $\begin{array}{l}\text { Mixed results with labour } \\
\text { productivity growth evident but } \\
\text { TFP growth lagging behind. }\end{array}$ \\
\hline O’Mahony (1998) & $\begin{array}{l}\text { Sectors of UK economy } \\
\text { including electricity, gas and } \\
\text { water }\end{array}$ & $\begin{array}{l}\text { Labour productivity and TFP in } \\
\text { the UK relative to US, France, } \\
\text { Germany and Japan }\end{array}$ & $\begin{array}{l}\text { Productivity gap declined in } \\
1995 \text { compared to 1989; but } \\
\text { evidence of a closing gap from } \\
\text { the } 1970 \text { s except relative to } \\
\text { France. }\end{array}$ \\
\hline
\end{tabular}




\begin{tabular}{|c|c|c|c|}
\hline Parker and $\mathrm{Wu}(1998)$ & $\begin{array}{l}\text { UK steel industry compared to } \\
\text { steel producers in } 6 \text { other } \\
\text { countries. }\end{array}$ & $\begin{array}{l}\text { DEA analysis of relative input- } \\
\text { output efficiency and } \\
\text { productivity figures. }\end{array}$ & $\begin{array}{l}\text { A large improvement in } \\
\text { relative performance occurred } \\
\text { in the British steel industry } \\
\text { before the privatisation. } \\
\text { Privatisation was followed by a } \\
\text { decline in relative } \\
\text { performance. }\end{array}$ \\
\hline Parker (1999b) & $\begin{array}{l}\text { British Airports Authority - } \\
\text { largest airport operator in the } \\
\text { UK privatised in July } 1987\end{array}$ & $\begin{array}{l}\text { DEA analysis of the relative } \\
\text { performance of BAA pre and } \\
\text { post-privatisation and the } \\
\text { relative performance of its } \\
\text { individual airports compared } \\
\text { with other airports in the UK } \\
\text { privately and publicly owned }\end{array}$ & $\begin{array}{l}\text { No evidence that privatisation } \\
\text { had a significant effect on } \\
\text { performance. Performance } \\
\text { improvements were a } \\
\text { continuation of a longer-term } \\
\text { trend. }\end{array}$ \\
\hline $\begin{array}{l}\text { Harris, Parker and Cox (1998); } \\
\text { Cox, Harris and Parker (1999) }\end{array}$ & $\begin{array}{l}\text { Procurement practices in } 28 \\
\text { privatised companies }\end{array}$ & Questionnaire and case studies & $\begin{array}{l}\text { Evidence of improvements in } \\
\text { procurement efficiency after } \\
\text { privatisation, but some firms } \\
\text { progressing faster than others } \\
\text { and few close to achieving best } \\
\text { practice. }\end{array}$ \\
\hline Saal and Parker $(2000,2001)$ & $\begin{array}{l}\text { Water and sewerage industry } \\
\text { in England and Wales. }\end{array}$ & $\begin{array}{l}\text { Labour and total factor } \\
\text { productivity and cost function. }\end{array}$ & $\begin{array}{l}\text { Privatisation led to no obvious } \\
\text { rise in productivity or lowered } \\
\text { costs of production. Higher } \\
\text { productivity and lower unit } \\
\text { costs came when the regulatory } \\
\text { price caps were tightened in } \\
1995 \text {. }\end{array}$ \\
\hline
\end{tabular}




\begin{tabular}{|c|c|c|c|}
\hline Pollitt and Domah (2001) & $\begin{array}{l}\text { Regional electricity companies } \\
\text { in England and Wales }\end{array}$ & $\begin{array}{l}\text { Social cost-benefit analysis } \\
\text { using a counterfactual }\end{array}$ & $\begin{array}{l}\text { Privatisation did yield } \\
\text { significant net social benefits, } \\
\text { but these were unevenly } \\
\text { distributed across time and } \\
\text { groups in society. } \\
\text { Government gained } £ 56 \mathrm{~m} \text { in } \\
\text { sales proceeds and taxes, but } \\
\text { consumers did not begin to } \\
\text { gain until } 2000 \text {. Producers } \\
\text { benefited from large increase } \\
\text { in after-tax profits. }\end{array}$ \\
\hline Pollitt and Smith (2002) & Britain's railways & $\begin{array}{l}\text { Social cost-benefit analysis } \\
\text { using a counterfactual }\end{array}$ & $\begin{array}{l}\text { Major efficiencies have been } \\
\text { achieved and consumers have } \\
\text { benefited from lower prices. } \\
\text { Increased government subsidy } \\
\text { has been largely recouped } \\
\text { through privatisation proceeds. } \\
\text { Output quality is not lower. }\end{array}$ \\
\hline Florio (2002) & $\begin{array}{l}\text { Social cost-benefit analysis of } \\
\text { UK privatisations in aggregate }\end{array}$ & $\begin{array}{l}\text { Labour and total factor } \\
\text { productivity, employment, } \\
\text { prices and abnormal returns to } \\
\text { investors. Econometric } \\
\text { analyses of structural breaks in } \\
\text { GDP growth and changes in } \\
\text { welfare. }\end{array}$ & $\begin{array}{l}\text { Privatisation has had no } \\
\text { noticeable effects in terms of } \\
\text { trends in productivity, } \\
\text { employment and price levels at } \\
\text { the firm or sector levels after } \\
\text { allowing for changes in } \\
\text { technology and input prices, } \\
\text { nor on GDP growth and } \\
\text { productivity at the national } \\
\text { level. Overall household } \\
\text { expenditure on utility services }\end{array}$ \\
\hline
\end{tabular}




\begin{tabular}{|c|c|c|c|}
\hline & & & $\begin{array}{l}\text { including coal and transport } \\
\text { remained remarkably stable at } \\
\text { around } 8 \% \text { of the total value of } \\
\text { consumers' expenditure: 'Our } \\
\text { overall result.....[is] ... that } \\
\text { taxpayers suffered a loss of } \\
£ 14 \text { bn., but this was cancelled } \\
\text { out by the equivalent transfer } \\
\text { to shareholders, workers' } \\
\text { welfare was probably slightly } \\
\text { negatively affected, but overall } \\
\text { this impact was negligible, } \\
\text { consumers enjoyed a perpetual } \\
\text { discount in prices worth less } \\
\text { that } £ 1,000 \text { for each British } \\
\text { citizen.... Apparently, far from } \\
\text { being a "revolution”, the great } \\
\text { divestiture was a reshuffling of } \\
\text { relative positions of various } \\
\text { agents, probably a regressive } \\
\text { one, with a rather modest } \\
\text { impact on aggregate economic } \\
\text { efficiency' (p.41). }\end{array}$ \\
\hline Shaoul (2003) & $\begin{array}{l}\text { National Air Traffic Services } \\
\text { (NATS) }\end{array}$ & Financial analysis & $\begin{array}{l}\text { The resulting PPP is not } \\
\text { financially viable given } \\
\text { revenues, costs and investment } \\
\text { needs. }\end{array}$ \\
\hline
\end{tabular}




\begin{tabular}{|l|l|l|l|}
\hline Florio (2003) & $\begin{array}{l}\text { BT's long-term performance } \\
\text { over 40 years }\end{array}$ & $\begin{array}{l}\text { Output, prices, revenues, costs, } \\
\text { employment, productivity, } \\
\text { profits and investment. }\end{array}$ & $\begin{array}{l}\text { The rate of growth of output } \\
\text { was higher before privatisation. } \\
\text { Prices fell with business users } \\
\text { and international calls the } \\
\text { biggest gainers. There was } \\
\text { evidence of capital for labour } \\
\text { substitution, while R\&D } \\
\text { expenditures fell as a } \\
\text { percentage of turnover. } \\
\text { Operating profits were stable } \\
\text { before and after privatisation } \\
\text { and privatisation had little } \\
\text { discernible effect on } \\
\text { productivity trends before } \\
1991, \text { when the introduction of } \\
\text { more competition and new } \\
\text { regulatory pressures led to } \\
\text { large gains. }\end{array}$ \\
& & & \\
& & &
\end{tabular}


Table 4: Comparative Productivity: Electricity, gas and water sectors, 1979-95

$$
(\mathrm{UK}=100)
$$

Labour

Productivity

(output per

$\underline{\text { hour) }}$
Total Factor

Productivity

1979

1989

1995

1979

1989

1995

USA 474

345

245

247

190

176

France $\quad 238$

255

173

101

110

99

Germany 202

156

103

149

116

97

Japan

180

155

107

117

88

73

Source: O’Mahony (1998).

Table 5: $\quad$ Price Reductions for Electricity Suppliers in Great Britain, 1990-1999 (\%)

Small users

Medium-sized users

Moderately-large users

Large users

Extra-large users

31

25

Source: Littlechild (2000, Figure 2, p.33). Note: Littlechild uses the term 'sites' instead of users. 
Table 6: Examples of Returns to Investors in the Privatised Utilities

$\%$ Returns to investors selling after:

\begin{tabular}{|c|c|c|c|c|c|c|c|}
\hline & 1 day & 1 year & & 5 years & & $\begin{array}{l}\text { Still held } \\
\text { at } 30 / 4 / 97\end{array}$ & \\
\hline BT (1) & 35 & 84 & $(+69)$ & 20 & $(+6)$ & 14 & $(+3)$ \\
\hline BT (2) & 5 & 22 & $(+5)$ & 10 & $(-3)$ & 12 & $(-2)$ \\
\hline $\mathrm{BT}(3)$ & 5 & 5 & $(-4)$ & - & - & 8 & $(-5)$ \\
\hline British Gas & 10 & 24 & $(+20)$ & 15 & $(+9)$ & 11 & $(+2)$ \\
\hline $\begin{array}{l}\text { Water and } \\
\text { Sewerage } \\
\text { (average) }\end{array}$ & 20 & 39 & $(+45)$ & 23 & $(+18)$ & 24 & $(+16)$ \\
\hline $\begin{array}{l}\text { RECs } \\
\text { Average }\end{array}$ & 23 & 41 & $(+29)$ & 40 & $(+27)$ & 38 & $(+25)$ \\
\hline Powergen (1) & 22 & 29 & $(+26)$ & 30 & $(+19)$ & 29 & $(+18)$ \\
\hline Powergen (2) & 3 & 9 & $(-14)$ & - & - & 16 & $(-3)$ \\
\hline $\begin{array}{l}\text { National } \\
\text { Power (1) }\end{array}$ & 22 & 22 & $(+19)$ & 28 & $(+17)$ & 30 & $(+19)$ \\
\hline $\begin{array}{l}\text { National } \\
\text { Power (2) }\end{array}$ & 4 & 6 & $(-17)$ & - & - & 23 & $(+4)$ \\
\hline
\end{tabular}

Notes:

1. Figures in parentheses show gains relative to movement of the FT- All Share Index over the same period. Returns are to individuals investing and are calculated as internal rates of return. Due to special incentive schemes the return to institutional investors is slightly lower.

2. All returns are real returns deflated using the RPI

3. 1 day return is an absolute IRR (not annualised). It shows the gain from first day's trading on the selling price. All other periods reflect annualised returns.

4. The lower first day returns on second and third tranches of shares sold reflect the fact that later issues are priced close to the current market price.

Source: Parker, 1997. 


\section{CESifo Working Paper Series}

(for full list see www.cesifo.de)

1061 Helmuth Cremer and Pierre Pestieau, Wealth Transfer Taxation: A Survey, October 2003

1062 Henning Bohn, Will Social Security and Medicare Remain Viable as the U.S. Population is Aging? An Update, October 2003

1063 James M. Malcomson, Health Service Gatekeepers, October 2003

1064 Jakob von Weizsäcker, The Hayek Pension: An efficient minimum pension to complement the welfare state, October 2003

1065 Joerg Baten, Creating Firms for a New Century: Determinants of Firm Creation around 1900, October 2003

1066 Christian Keuschnigg, Public Policy and Venture Capital Backed Innovation, October 2003

1067 Thomas von Ungern-Sternberg, State Intervention on the Market for Natural Damage Insurance in Europe, October 2003

1068 Mark V. Pauly, Time, Risk, Precommitment, and Adverse Selection in Competitive Insurance Markets, October 2003

1069 Wolfgang Ochel, Decentralising Wage Bargaining in Germany - A Way to Increase Employment?, November 2003

1070 Jay Pil Choi, Patent Pools and Cross-Licensing in the Shadow of Patent Litigation, November 2003

1071 Martin Peitz and Patrick Waelbroeck, Piracy of Digital Products: A Critical Review of the Economics Literature, November 2003

1072 George Economides, Jim Malley, Apostolis Philippopoulos, and Ulrich Woitek, Electoral Uncertainty, Fiscal Policies \& Growth: Theory and Evidence from Germany, the UK and the US, November 2003

1073 Robert S. Chirinko and Julie Ann Elston, Finance, Control, and Profitability: The Influence of German Banks, November 2003

1074 Wolfgang Eggert and Martin Kolmar, The Taxation of Financial Capital under Asymmetric Information and the Tax-Competition Paradox, November 2003

1075 Amihai Glazer, Vesa Kanniainen, and Panu Poutvaara, Income Taxes, Property Values, and Migration, November 2003 
1076 Jonas Agell, Why are Small Firms Different? Managers’ Views, November 2003

1077 Rafael Lalive, Social Interactions in Unemployment, November 2003

1078 Jean Pisani-Ferry, The Surprising French Employment Performance: What Lessons?, November 2003

1079 Josef Falkinger, Attention, Economies, November 2003

1080 Andreas Haufler and Michael Pflüger, Market Structure and the Taxation of International Trade, November 2003

1081 Jonas Agell and Helge Bennmarker, Endogenous Wage Rigidity, November 2003

1082 Fwu-Ranq Chang, On the Elasticities of Harvesting Rules, November 2003

1083 Lars P. Feld and Gebhard Kirchgässner, The Role of Direct Democracy in the European Union, November 2003

1084 Helge Berger, Jakob de Haan and Robert Inklaar, Restructuring the ECB, November 2003

1085 Lorenzo Forni and Raffaela Giordano, Employment in the Public Sector, November 2003

1086 Ann-Sofie Kolm and Birthe Larsen, Wages, Unemployment, and the Underground Economy, November 2003

1087 Lars P. Feld, Gebhard Kirchgässner, and Christoph A. Schaltegger, Decentralized Taxation and the Size of Government: Evidence from Swiss State and Local Governments, November 2003

1088 Arno Riedl and Frans van Winden, Input Versus Output Taxation in an Experimental International Economy, November 2003

1089 Nikolas Müller-Plantenberg, Japan’s Imbalance of Payments, November 2003

1090 Jan K. Brueckner, Transport Subsidies, System Choice, and Urban Sprawl, November 2003

1091 Herwig Immervoll and Cathal O'Donoghue, Employment Transitions in 13 European Countries. Levels, Distributions and Determining Factors of Net Replacement Rates, November 2003

1092 Nabil I. Al-Najjar, Luca Anderlini \& Leonardo Felli, Undescribable Events, November 2003

1093 Jakob de Haan, Helge Berger and David-Jan Jansen, The End of the Stability and Growth Pact?, December 2003 
1094 Christian Keuschnigg and Soren Bo Nielsen, Taxes and Venture Capital Support, December 2003

1095 Josse Delfgaauw and Robert Dur, From Public Monopsony to Competitive Market. More Efficiency but Higher Prices, December 2003

1096 Clemens Fuest and Thomas Hemmelgarn, Corporate Tax Policy, Foreign Firm Ownership and Thin Capitalization, December 2003

1097 Laszlo Goerke, Tax Progressivity and Tax Evasion, December 2003

1098 Luis H. B. Braido, Insurance and Incentives in Sharecropping, December 2003

1099 Josse Delfgaauw and Robert Dur, Signaling and Screening of Workers' Motivation, December 2003

1100 Ilko Naaborg,, Bert Scholtens, Jakob de Haan, Hanneke Bol and Ralph de Haas, How Important are Foreign Banks in the Financial Development of European Transition Countries?, December 2003

1101 Lawrence M. Kahn, Sports League Expansion and Economic Efficiency: Monopoly Can Enhance Consumer Welfare, December 2003

1102 Laszlo Goerke and Wolfgang Eggert, Fiscal Policy, Economic Integration and Unemployment, December 2003

1103 Nzinga Broussard, Ralph Chami and Gregory D. Hess, (Why) Do Self-Employed Parents Have More Children?, December 2003

1104 Christian Schultz, Information, Polarization and Delegation in Democracy, December 2003

1105 Daniel Haile, Abdolkarim Sadrieh and Harrie A. A. Verbon, Self-Serving Dictators and Economic Growth, December 2003

1106 Panu Poutvaara and Tuomas Takalo, Candidate Quality, December 2003

1107 Peter Friedrich, Joanna Gwiazda and Chang Woon Nam, Development of Local Public Finance in Europe, December 2003

1108 Silke Uebelmesser, Harmonisation of Old-Age Security Within the European Union, December 2003

1109 Stephen Nickell, Employment and Taxes, December 2003

1110 Stephan Sauer and Jan-Egbert Sturm, Using Taylor Rules to Understand ECB Monetary Policy, December 2003

1111 Sascha O. Becker and Mathias Hoffmann, Intra-and International Risk-Sharing in the Short Run and the Long Run, December 2003 
1112 George W. Evans and Seppo Honkapohja, The E-Correspondence Principle, January 2004

1113 Volker Nitsch, Have a Break, Have a ... National Currency: When Do Monetary Unions Fall Apart?, January 2004

1114 Panu Poutvaara, Educating Europe, January 2004

1115 Torsten Persson, Gerard Roland, and Guido Tabellini, How Do Electoral Rules Shape Party Structures, Government Coalitions, and Economic Policies? January 2004

1116 Florian Baumann, Volker Meier, and Martin Werding, Transferable Ageing Provisions in Individual Health Insurance Contracts, January 2004

1117 Gianmarco I.P. Ottaviano and Giovanni Peri, The Economic Value of Cultural Diversity: Evidence from US Cities, January 2004

1118 Thorvaldur Gylfason, Monetary and Fiscal Management, Finance, and Growth, January 2004

1119 Hans Degryse and Steven Ongena, The Impact of Competition on Bank Orientation and Specialization, January 2004

1120 Piotr Wdowinski, Determinants of Country Beta Risk in Poland, January 2004

1121 Margarita Katsimi and Thomas Moutos, Inequality and Redistribution via the Public Provision of Private Goods, January 2004

1122 Martin Peitz and Patrick Waelbroeck, The Effect of Internet Piracy on CD Sales: CrossSection Evidence, January 2004

1123 Ansgar Belke and Friedrich Schneider, Privatization in Austria: Some Theoretical Reasons and First Results About the Privatization Proceeds, January 2004

1124 Chang Woon Nam and Doina Maria Radulescu, Does Debt Maturity Matter for Investment Decisions?, February 2004

1125 Tomer Blumkin and Efraim Sadka, Minimum Wage with Optimal Income Taxation, February 2004

1126 David Parker, The UK's Privatisation Experiment: The Passage of Time Permits a Sober Assessment, February 2004 